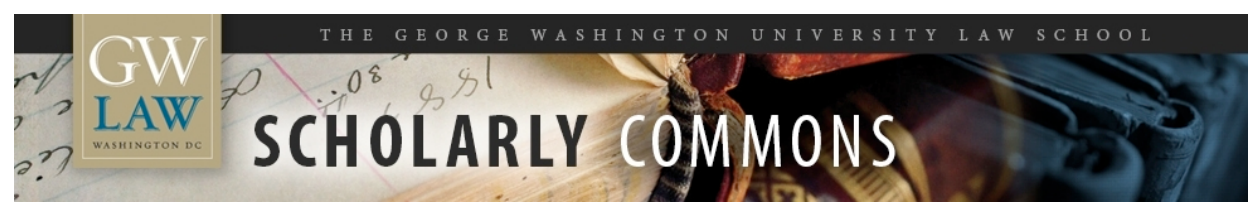

\title{
Private Antitrust at the U.S. International Trade Commission
}

\author{
F. Scott Kieff \\ George Washington University Law School, skieff@law.gwu.edu
}

Follow this and additional works at: https://scholarship.law.gwu.edu/faculty_publications

Part of the Law Commons

\section{Recommended Citation}

Kieff, F. Scott, Private Antitrust at the U.S. International Trade Commission (March 19, 2018). Journal of Competition Law \& Economics (Oxford University Press), Forthcoming; GWU Law School Public Law Research Paper No. 2018-16; GWU Legal Studies Research Paper No. 2018-16. Available at SSRN: https://ssrn.com/abstract=3144513

This Article is brought to you for free and open access by the Faculty Scholarship at Scholarly Commons. It has been accepted for inclusion in GW Law Faculty Publications \& Other Works by an authorized administrator of Scholarly Commons. For more information, please contact spagel@law.gwu.edu. 
Private Antitrust at the U.S. International Trade Commission

By

F. Scott Kieff ${ }^{1}$

\section{INTRODUCTION}

The basic structure of the statute governing the U.S. International Trade Commission (ITC) is grounded in the Smoot-Hawley Tariff Act of $1930 .^{2}$ The adjudicatory portions of the ITC's docket arising from this statute are generally recognized to include two basic categories of cases (more precisely termed "investigations"): the Title VII portion, which is filled mostly with issues of antidumping and countervailing duty law; and the Section 337 portion, sometimes also referred to as the "unfair competition" portion, which is filled mostly with issues of intellectual property law. ${ }^{3}$ For the Title VII portion, a longstanding concern has been that these cases essentially run too high of a ratio of risk to reward for the overall societal benefit. The low reward is because Title VII cases proceed without any requirement there be evidence of actual or threatened economic harm to the

\footnotetext{
${ }^{1}$ As of 01 July 2017, the author is serving as Fred C. Stevenson Research Professor at George Washington University Law School and Senior Fellow at Stanford University's Hoover Institution. Beginning 18 December 2017 he is also serving as Principal in the DC office of the McKool Smith law firm. From 18 October 2013 until stepping down on 30 June 2017, the author was a Commissioner of the US International Trade Commission (ITC) who participated in the investigation captioned Certain Carbon and Alloy Steel Products, Inv. No. 337-TA-1002, which involves among other topics a complaint by a private litigant alleging violations of the antitrust laws. The views expressed herein are presented in this fashion to preserve for public review a more detailed explanation of the ideas already made part of the public record of that investigation by the questions the author asked the parties at the oral argument held by the ITC on 20 April 2017 regarding the Administrative Law Judge's Order No. 38, which was issued 14 November 2016. These views are those of the author only, having been reached in his role as an individual adjudicator in that investigation, and are not properly attributable to the ITC or any of its other Members or Staff; and they take no position on any other pending or proposed legislative or other governmental actions. The author gratefully acknowledges the many helpful contributions to these ideas from the parties, their counsel, members of the commenting public, and the ITC staff. The agency's prepublication ethics review and resulting clearance to ensure avoidance of any impropriety or appearance thereof is also gratefully acknowledged.

2 Tariff Act of 1930 (Smoot-Hawley Tariff Act), Pub. L. No. 71-361, ch. 497, 46 Stat. 590 (1930) (codified in various sections of Title 19 of the United States Code).

${ }^{3}$ For a review of the ITC's law and practice in these areas, see, generally, F. Scott Kieff, Pragmatism, Perspectives, and Trade: AD/CVD, Patents, and Antitrust as Mostly Private Law, 30 HARV. J. L.\& TECH. 97 (2017).
} 
market as a whole. ${ }^{4}$ The high risk is that these cases can have the effect of merely picking particular winners and losers within our economy by issuing orders that protect those investing capital and labor into the particular domestic industries that are subject to the orders while raising prices paid by those investing capital and labor in the industries for which the subject products are inputs to downstream production, as well as prices paid by consumers for final products. ${ }^{5}$ In response to such concerns about overall social benefit, commentators have recommended that Congress should import into these international trade laws many of the limits now recognized in modern antitrust law to focus in on true economic harm to markets by incorporating key lessons about error costs learned over the past century in institutional economics, such as the requirement that adjudication of complaints about low pricing turn on proof of actual predatory pricing. ${ }^{6}$

This paper, drafted as an adjudicator's opinion in a recent case of nearly first impression, ${ }^{7}$ explores a different approach to aligning the strengths and opportunities available through the ITC by considering how more ordinary antitrust issues can be adjudicated through the Section 337 portion of the ITC's docket. This might be done using existing law. The basic theme is that there are several significant reasons why even a Title VII skeptic - as well as an antitrust skeptic should be significantly less worried when cases normally expected to be brought in the Title VII portion of the ITC's docket as petitions are instead brought in the Section 337 portion of the ITC docket as complaints alleging ordinary violations of the antitrust laws.

Private antitrust litigation fits well within the ITC's Section 337 docket for several reasons. It squarely fits with the plain meaning of the ITC's statute. It also squarely fits the well-established antitrust case law. In addition, it offers some practical benefits. Unlike the relatively easy-to-satisfy legal requirement for assessing injury in the Title VII portion of the docket, ${ }^{8}$ a 337 investigation involving

\footnotetext{
${ }^{4}$ This is compared with Title VII's capacious understanding of what counts as injury to the relevant industry. The requirement in the Title VII portion of the docket regarding injury to the industry is generally seen as being very low, strongly favoring an affirmative determination. See Kieff, supra, note 3 , at $100-105$

${ }^{5}$ See, e.g., Alen O. Sykes, Countervailing Duty Law: An Economic Perspective, 89 CoLuM. L. REV. 199 (1989).

${ }^{6}$ See, e.g., J. Gregory Sidak, A Framework for Administering the 1916 Antidumping Act: Lessons from Antitrust Economics, 18 StAn. J. InT'L L. 377 (1982); Alden Abbott, U.S. Antidumping Law Needs a Dose of Free-Market Competition, Heritage Foundation Backgrounder \#3030 on Trade (July 17, 2015) (arguing that actual predatory pricing should be proven before antidumping investigations should be allowed to proceed).

${ }^{7}$ See infra note 11 and accompanying text.

${ }^{8}$ See supra note 4.
}

(Page 2 of 20) 
established antitrust law would turn on the substantive legal standards within that body of established antitrust law that are seen by a broad consensus to be focused on a middle of the road attempt to represent true public interest in avoiding actual economic harm to a market as a whole. In addition, a 337 investigation, which involves initial inter-partes adversarial litigation before an Administrative Law Judge (ALJ), implicates less reliance on administrative deference than an action in the Title VII portion of the docket, and more reliance than in the Title VII portion of the docket on a detailed factual record involving the full panoply of procedural devices ordinarily available in federal court for truth-testing of evidence including cross examination of testimony, all in a timeframe likely to be significantly shorter (around 18 months) than the many years typically required for antitrust litigation in federal court. ${ }^{9}$

Nevertheless, at least one recent high-profile dispute shows there is at least one significant barrier that may stand as a practical obstacle to a private litigant bringing an antitrust claim under the Section 337 portion of the ITC's docket: the doctrine that federal courts developed called "antitrust injury,"10 During the initial phases of such a case recently brought against Chinese importers of steel by the domestic US steel industry, with support from both companies and unions, the ALJ dismissed the antitrust complaint for lack of antitrust injury in an initial determination that was then reviewed by the Commission. ${ }^{11}$ This paper explores some reasons why the antitrust injury doctrine from federal court may not be a good fit for investigations brought under Section 337 at the ITC.

\footnotetext{
${ }^{9}$ For more on the procedural benefits of the Section 337 portion of the ITC's docket, see F. Scott Kieff, A Stylized Model of Agency Structure for Mitigating Executive Branch Overreach, in DEAN REUTER \& JoHN YOO, LIBERTY's NEMESIS: THE UnCHECKED EXPANSION OF THE STATE, at 191-207 (2016) (Encounter Books).

${ }^{10}$ See infra, note 14 , and accompanying text.

${ }^{11}$ Certain Carbon and Alloy Steel Products, Inv. No. 337-TA-1002, Order No. 38 (Nov. 14, 2016). On December 19, 2016, the Commission issued a notice determining to review the initial determination (Order No. 38). See 81 Fed. Reg. 94416-17 (Dec. 23, 2016). On March 19, 2018, the ITC issued a determination to affirm the ALJ's order, with a dissenting opinion by Commissioner Broadbent. Certain Carbon and Alloy Steel Products, Inv. No. 337-TA-1002, Commission Opinion and Dissenting Opinion by Commissioner Broadbent (Mar. 19, 2018). The Commission Opinion followed reasoning similar to that of the ALJ, although dismissed the complaint without prejudice. Writing in dissent, Commissioner Broadbent elaborated the extensive legislative history and surrounding case law supporting the view that Section 337 confers broad unfair competition jurisdiction on the ITC. Regardless of which party appears to be winning this phase of the dispute before the ITC, at the oral argument before the Commission regarding Order No. 38, each side expressed high confidence it would win on appeal regarding its side of the debate about whether the antitrust injury doctrine is required in a private antitrust complaint under Section 337 at the ITC. See Transcript of Oral Argument Before the Commission on April 20, 2017, at pp. 260-262 (April 21, 2017) (“Oral Argument Transcript”).
}

(Page 3 of 20) 


\section{The Recent Private ANtitrust Litigation Under 337 AT THE ITC}

The central arguments offered by the respondents in this recent case can be fairly summarized briefly. The argument posits that because a complaint at the ITC under Section 337 that invokes an antitrust claim such as this one is brought at the initiation of a private party, it is analogous to antitrust litigation brought by private plaintiffs in Federal Court under the Clayton Act. Respondents would therefore have the ITC require the private complainant to plead and prove the same private antitrust injury that courts require in such cases brought before them under the Clayton Act.

Yet, the private antitrust injury practice from the federal courts does not appear to be a good fit for importation into ITC practice because it is not required by either the ITC's statute or the substantive antitrust statute. ${ }^{12}$ The analogy drawn by Respondents, while evident at first blush in that both actions are initiated by private parties, almost entirely breaks down on functional grounds when the logic of the private antitrust injury doctrine is followed on its own terms.

\section{A. The Plain Meaning of the ITC's Statute}

The ITC's statute is one of the customs and international trade laws in Title 19 of the United States Code. The ITC's statute refers to the substantive unfair competition laws of other Titles of the United States Code. It makes explicit reference to Title 35 for patents, Title 17 for Copyrights, and Title 15 for trademarks. It also makes explicit reference to unlawful conduct that must be dealt with by the ITC if it involves the type of unfair competition, the threat or effect of which is to destroy, substantially injure, or prevent the establishment of an industry,

\footnotetext{
${ }^{12}$ As the Federal Circuit recently reminded, the absence of express limit in the ITC's statute against the reach of the ITC's statute militates heavily against importing such a limit as a matter of law. TianRui Group Co., Ltd. v. U.S. Int'l Trade Comm 'n, 661 F.3d 1322 (Fed. Cir. 2011) (affirming Commission determination that trade secret laws of the United States can apply to conduct abroad and declining to import the general presumption against extraterritorial application of U.S. law because the ITC's statute, on its own terms, directs the ITC to act at the point of importation.). Furthermore, while concerns have been raised about the different substantive standards for trade secret law between China and the United States, the unfair acts complained of in this investigation are of a type recognized to be prohibited under the antitrust laws of both the United States and China. See Complainant U.S. Steel's Petition for Review of the Initial Determination Granting Respondents' Motion to Terminate U.S. Steel's Antitrust Claim Under 19 C.F.R. $\S 210.21$ and, in the Alternative, Under 19 C.F.R. $\S 210.18$, at p. 12 n.4 \& Exhibit 1 (November 23, 2016); Complainant U.S. Steel's Written Submissions Regarding the Commission's Determination to Review an Initial Determination Granting Respondents' Motion to Terminate Complainant's PriceFixing Claim, at p. 22-23 \& Exhibit 1 (January 17, 2017); and Oral Argument Transcript, at p. 11.
} 
or to restrain or monopolize trade and commerce. At least this last category market restraint and monopolization - appears on its face to be the same type of unlawful unfair competition that is the subject of the substantive antitrust provisions in Title 15 promulgated through the Sherman Act and Clayton Act, among others.

The Clayton Act authorizes private parties to sue in federal court when they have been harmed by a violation of the antitrust laws, such as the Sherman Act or other sections of the Clayton Act. ${ }^{13}$ The Supreme Court has interpreted the private enforcement provisions of the Clayton Act to require the private antitrust plaintiff in court to plead and prove private antitrust injury. ${ }^{14}$ The Court has further pointed out that "in the context of pricing practices, only predatory pricing has the requisite anticompetitive effect," 15 for which there is a two-prong test: "[f]irst, a plaintiff. . must prove that that the prices complained of are below an appropriate measure of its rival's costs" ("below-cost pricing"); and "[t]he second prerequisite . . . is a demonstration that the competitor had . . . a dangerous probability, of recouping its investment in below-cost prices."16

In essence, Respondents seek dismissal of the antitrust claim in this investigation because they see such a claim as requiring the complainants to plead and prove below cost pricing and recoupment. Claimants concede that dismissal would be appropriate if such a private antitrust injury doctrine were required at the ITC. This is because, for steel made in China, Complainants concede they have no meaningful ability to show much about either cost or recoupment. Complainant's infirmity may be in part because of the difficulty conducting discovery in China and in part because of the significant role of the Chinese national government in

\footnotetext{
13 See, e.g., 15 U.S.C. $\S \S 15,26 ;$ Atl. Richfield Co. v. USA Petroleum Co., 495 U.S. 328, 331-32 (1990) (ARCO). Under section 4 of the Clayton Act, "any person who shall be injured in his business or property by reason of anything forbidden in the antitrust laws may sue therefor ... and shall recover threefold the damages by him sustained, and the cost of suit, including a reasonable attorney's fee." 15 U.S.C. $§ 15(a)$. Under section 16 of the Clayton Act, "[a]ny person, firm, corporation, or association shall be entitled to sue for and have injunctive relief . . against threatened loss or damage by a violation of the antitrust laws ...." 15 U.S.C. $\S 26$.

14 See ARCO, 495 U.S. at 334 ("A private plaintiff may not recover damages under $\S 4$ of the Clayton Act merely by showing 'injury causally linked to an illegal presence in the market.' . . . Instead, a plaintiff must prove the existence of 'antitrust injury, which is to say injury of the type the antitrust laws were intended to prevent and that flows from that which makes defendants' acts unlawful."”) (citing Brunswick Corp. v. Pueblo Bowl-O-Mat, Inc., 429 U.S. 477, 489 (1977) ("Brunswick") (italics emphasis in original).

${ }^{15}$ ARCO, 495 U.S. at 339 (citations omitted).

${ }^{16}$ See Brooke Group, Ltd. v. Brown \& Williamson Tobacco Corp., 509 U.S. 209, 222-24 (1993) (citations omitted).
} 
the operations of the national economy in general and particular business firms in particular. ${ }^{17}$

On the legal question about what is needed for their antitrust case to proceed before the ITC, Complainants have a different take. They argue that their antitrust claim(s) should proceed before the ITC whether focused on price fixing or on other horizontal agreements spanning a much broader spectrum of behaviors than merely predatorily low price. This approach is easier for me to follow for the reasons explained below.

Section 337 instructs the ITC to investigate and adjudicate claims of "[u]nfair methods of competition and unfair acts in the importation of articles ... into the United States, or in the sale of such articles by the owner, importer, or consignee, the threat or effect of which is . . to restrain or monopolize trade and commerce in the United States." 18 As recognized in early Commission cases, "[t]his prohibition is generally modeled after section 1 of the Sherman Antitrust Act (15 U.S.C. § 1)." ${ }^{\prime 19}$

Complainants in this case seek, inter alia, relief from injury caused by Respondents' "conspiracy to fix prices and control output and export volumes, in violation of Section 1 of the Sherman Act, 15 U.S.C. $\S 1 .{ }^{\prime 20}$ Although at oral argument there appeared to be some lack of clarity about which provision of the ITC's statute was invoked on what date and by whom regarding the antitrust issues in this case, ${ }^{21}$ at present there are two particular statutory hooks on which the Complainants hope to hang their case. They rely on either Section 337 (a)(1)(A)(i) or (iii), which prevent acts of unfair competition, the threat or effect of which is: "(i) to destroy or substantially injure an industry in the United States; ... [or] (iii) to restrain or monopolize trade and commerce in the United States." ${ }^{22}$ Simply put, they complain of harm to a domestic industry under (i) and harm to "trade and commerce" under (iii).

\footnotetext{
17 One challenge of applying U.S. predatory pricing jurisprudence to companies in a country employing extensive state ownership is that they are less likely to be profit-maximizing firms over the same time horizon as U.S. firms. See, David E.M. Sappington \& J. Gregory Sidak, 71 ANTITRUST L. J. 479 (2003).

1819 U.S.C. $\S 1337$ (a)(1)(A)(iii).

${ }^{19}$ See Certain Airtight Cast-Iron Stoves, Inv. No. 337-TA-69, Comm'n Op., 1980 WL 41970, *3 (Dec. 31, 1980).

${ }^{20}$ Complaint Under Section 337 of the Tariff Act of 1930, as Amended, at 2 (Apr. 26, 2016).

21 The Commission has a practice of allowing some leeway in how complaints are amended and interpreted.

2219 U.S.C. 1337(a)(1)(A). See, e,g., Oral Argument Transcript, pp. 34-35.
} 
Past Commission determinations relating to these provisions in the ITC's statute have recognized that by the end of an investigation brought under these provisions, the complainant must have shown actual injury either to the industry or to trade and commerce before the Commission will order a remedy. For example, the Commission determined that "[Section 337] contains a separate requirement of injury, either to competition or to competitors," i.e., "[t]he party with the burden of proof must show by substantial, probative and reliable evidence that either injury or a restraint of trade is taking place, or that there is a tendency toward them."23

But no Commission determination applying these provisions of the ITC's Section 337 statute has imported the antitrust injury doctrine from cases brought under the Clayton Act in district court. Some important differences between the two statutory regimes may explain why.

One stark difference between the two statutory regimes ${ }^{24}$ relates to the explicit goals that the statutes state for themselves. The ITC's statute explicitly states it is to remedy harm to the industry or harm to trade and commerce. ${ }^{25}$ By contrast, the Clayton Act explicitly states it is to remedy harm to only the plaintiff itself. $^{26}$ This difference has particular significance for the issue now before the Commission because the Supreme Court's source of the private antitrust injury doctrine, its decision in Brunswick, explicitly tied the doctrine to this particular goal of the Clayton Act. More particularly, much of the Court's discussion in Brunswick focuses on the role the doctrine plays in mitigating the risk of unjustly enriching the plaintiff with damages awards beyond the amount of the particular antitrust

23 Certain Welded Stainless Steel Pipe and Tube, Inv. 337-TA-29, Opinion of Commissioners Minchew, Moore and Alberger, 1978 WL 50692, *17 (Feb. 22, 1978) ("Steel Pipe"). See also Certain Tractor Parts, Inv. No. 337- 22, U.S. Tariff Commission Pub. No. 443, Commission Ruling on Motion for Dismissal for Lack of Jurisdiction, at A-45 (December, 1971) ("Section 337 directs the imposition of an exclusion order in a case where an unfair method or act has the effect or tendency 'to restrain or monopolize trade and commerce in the United States' irrespective of whether a domestic industry is experiencing injury.") (quoting the statute).

${ }^{24}$ On the one hand are these provisions of the ITC's statute, under which complainants are seeking to proceed here before the Commission, and on the other hand are the provisions of the Clayton Act under which private parties may proceed in district court.

2519 U.S.C. 1337(a)(1)(A) ("(i) to destroy or substantially injure an industry in the United States; [or] ... (iii) to restrain or monopolize trade and commerce in the United States") (emphasis added).

${ }^{26}$ Section 4 of the Clayton Act explicitly references the plaintiff's own injury as the basis for both the suit and the recovery. 15 U.S.C. $\S 15$ (a) (“. . . any person who shall be injured in his business or property ... may sue therefor ... and shall recover threefold the damages by him sustained, and the cost of suit, including a reasonable attorney's fee.") (emphasis added). 
harm that plaintiff actually suffered. ${ }^{27}$ The doctrine makes sense in the context of the Clayton Act proceedings in federal court because it keeps the cause of action focused on that statute's stated goal of protecting a particular litigant only in so far as that party itself is a proxy for the harm to the market. By contrast, since the goal of the ITC's statute is to remedy for harm to the industry or to trade and commerce - and such harms would have to be eventually shown in a case like ours before a remedy would be imposed - there is no need to closely tie such broader harms to the market to the precise amounts of harms suffered by the particular complainant.

A second key difference between these two statutory regimes relates to the different mechanisms the statutes use to accomplish their goals. The remedy provisions of the Clayton Act benefit much more than just the private plaintiff. They are designed to benefit the public, echoing the view that the private plaintiff is serving, indirectly, as a proxy for the market as a whole. For example, the enhanced damages provisions of the Clayton Act, including treble damages and attorney fees, provide general deterrence against anticompetitive conduct. In addition, the broad equitable power of the injunction has allowed courts and agencies to deploy myriad structural remedies to provide future protection against such conduct. In a sense, this mix of remedies is designed to reward the prospecting risks of a private plaintiff incurring the costs to act as a private attorney general, but under the private antitrust injury doctrine, such remedies must then be reinedin to ensure they are not used to unjustly enrich that particular plaintiff with remuneration beyond the particular antitrust harm it actually suffered or to deter pro-competitive conduct of defendants in general. By contrast, the provisions in Section 337(a)(1)(A)(i) and (iii), however, are much more direct in that they protect against injury to the industry ${ }^{28}$ or to trade and commerce more broadly. Harm to the particular complainant is essentially only relevant in so far as it shows harm to the industry or to trade and commerce more broadly. In turn, the remedies the ITC's statute provides are more modest and direct in stopping any such broader harm that is determined to exist through a complete investigation. The remedies available under the ITC's statute are limited to an exclusion order and a cease and desist order. ${ }^{29}$ The directness of the Commission's statute decreases the risk of the errors associated with the indirectness of a proxy approach. Furthermore, the more

\footnotetext{
${ }^{27}$ See Brunswick, 429 U.S. at $486-87$.

${ }^{28}$ To be sure, the industry includes its workers, who routinely appear at the ITC on their own behalf as well, as they have in this case.

${ }^{29}$ The distinction between the Commission's remedies and district court injunctions was explored in a different context by the Federal Circuit in Spansion, Inc. v. Int'l Trade Comm'n, 629 F.3d 1331 (Fed. Cir. 2010).
} 
limited scope of the remedies available under Section 337 decreases the harm from any such errors that do occur. ${ }^{30}$

\section{B. Antitrust Error Cost Analysis and Nature of Allegedly Harmful Conduct}

Distinguishing the different categories of error risk that are inherent in particular underlying antitrust arguments reveals additional reasons why the private antitrust injury doctrine appears to be a particularly poor fit for a Commission case involving the type of antitrust issues raised here. As with many fields of law, error cost analysis is central to antitrust, because the legal and the economic components of judgments in this area are prone to both over inclusiveness and under inclusiveness. In large part this is because antitrust analysis requires a significant number of educated guesses about possible alternative states of the world that either did not come into existence or have not yet come into existence. It also may be due to the inherent complexity of the issues and the inevitable confusion that sometimes follows jargon.

Even in areas of antitrust in which there might at first blush appear to be broad consensus, there can be found much more variation on closer inspection. For example, significant debate has long existed in antitrust about what types of horizontal agreements - agreements among competitors - are bad for the economy, even though horizontal agreements might be seen as the clearest example of a type of conduct prohibited by our antitrust laws since they are the focus of the very first section of our Nation's very first antitrust law, Sherman Act Section 1. Most recognize that some may be good, such as those involving certain technological standards. Consider an agreement among car manufacturers to build cars best adapted for driving on only one side of the road to foster the social goal of accident avoidance. According to the OECD, "agreements between competitors related to research \& development, production and marketing can result in reduced costs for companies, or improved products, the benefits of which are passed on to consumers." ${ }^{31}$ Most also recognize that some may be bad, such as so-called hard core cartels restricting the key competitive parameters of price, output, quality, variety, or innovation. According to the OECD, the categories of horizontal

\footnotetext{
${ }^{30}$ Simply put, at the conclusion of an investigation in a case such as this one, if the Commission ultimately determines there to have been a violation, the extent of the remedy available from the Commission is essentially only that the products in question would be excluded from the U.S. market, perhaps augmented by a cease and desist order limited to particular named parties who either appeared before the Commission and lost after having had a full and fair opportunity to argue the merits of their case, or chose to default.

31 See http://www.oecd.org/competition/cartels/.
} 
agreements "most often defined as hard core cartels are: price fixing, output restrictions, market allocation, and bid rigging." 32

The complexity of the antitrust landscape extends deeper from there along several dimensions. Even practices ordinarily otherwise viewed under the per se rule have been allowed by courts in certain circumstances where there were appropriate countervailing benefits to the conduct. ${ }^{33}$ In addition, while at least certain horizontal agreements have long been recognized to be subject to treatment as per se antitrust violations in the United States, significant debates exist over which of the many other types of conduct should be treated as per se violations, or subject to a rule of reason analysis, as well as whether some middle-level scrutiny should be employed in particular settings, such as quick look. ${ }^{34}$ In non-per se cases, subject to a rule of reason analysis, pro-competitive effects of the allegedly anticompetitive conduct are considered. ${ }^{35}$ Furthermore, in appropriate settings, a particular restraint that would be illegal standing alone may be permitted if merely ancillary to an agreement that is otherwise globally legal in that it is determined to be efficiency enhancing while the particular restraint in question is reasonably related and reasonably necessary to the pro-competitive effects of the overall agreement. ${ }^{36}$

The Supreme Court, itself, has made clear on multiple occasions that lurking behind all of antitrust is vigilance about error costs. As the Supreme Court put it: "[m]istaken inferences and the resulting false condemnations 'are especially costly, because they chill the very conduct the antitrust laws are designed to protect."'37 This concern is echoed in significant academic debate, much of which has focused on predatory pricing and the risks of over-enforcement of antitrust laws. ${ }^{38}$ It is in

\footnotetext{
32 Id.

${ }^{33}$ See, e.g., Broadcast Music, Inc. v. CBS, 441 U.S. 1 (1979); NCAA v. Board of Regents, 468 U.S. 85 (1984); United States v. Brown Univ., 5 F.3d 658 (3d Cir. 1993).

${ }^{34}$ See, e.g., Alan J. Meese, Farewell to the Quick Look: Redefining the Scope and Content of the Rule of Reason, 68 Antitrust L.J. 461 (2000).

35 See, e.g., California Dental Ass'n v. Fed. Trade Comm'n, 526 U.S. 756, 771-74 (1999) (discussing the particular issues for ordinary lay consumers arising from misleading and unverifiable claims by the skilled and licensed professions, including information asymmetries).

${ }^{36}$ See Federal Trade Comm. \& U.S. Dept. of Justice, Antitrust Guidelines for Collaborations Among Competitors, § 3.2 at 8-9 (2000).

37 Verizon Commc'ns Inc. v. Law Offices of Curtis V. Trinko, LLP, 540 U.S. 398, 414 (2004) (quoting Matsushita Elec. Indus. Co. v. Zenith Radio Corp., 475 U.S. 574, 594 (1986)).

38 See, e.g., Phillip Areeda \& Donald F.Turner, Predatory Pricing and Related Practices Under Section 2 of the Sherman Act, 88 Harv. L.Rev. 697 (1975); Oliver E. Williamson, Predatory Pricing: A Strategic and Welfare Analysis, 87 Yale L.J. 284 (1977); Robert H. Bork, The Antitrust Paradox 154-55 ([Basic Books, Inc.) (1978); Paul L. Joskow \& Alvin K. Klevorick, A Framework for
} 
direct response to these concerns, that the courts have adopted a number of safeguard measures. For example, the Supreme Court has explained that "it is only after considerable experience with certain business relationships that courts classify them as per se violations" of the antitrust laws. ${ }^{39}$ Similarly, the requirement for private litigants to plead and prove recoupment in a predatory pricing case was designed to test the plausibility of the plaintiff's anticompetitive explanation. ${ }^{40}$ That doctrine also provides important mitigation against the risk of plaintiffs shaking down antitrust defendants for high pecuniary settlements by raising the threat of significant damage awards, further boosted by trebling and fee-shifting as well as by the high transaction costs of potential class action litigation.

Most of the cases relied upon by Respondents in this investigation to support the imposition of the private antitrust standing doctrine involve forms of conduct that have long been treated as significantly less likely to be anticompetitive (and likely even pro-competitive) by the courts than the type of hard core cartel conduct that is alleged in this complaint. These are all settings in which an especially heightened scrutiny of the plaintiff's complaint is warranted. Such heightened scrutiny mitigates one type of error cost: the over-inclusiveness in antitrust enforcement that runs the risk of chilling what may otherwise be procompetitive conduct.

For example, $A R C O$ was brought under Section 4 of the Clayton Act and turned on "the question whether a firm incurs an 'injury' within the meaning of the antitrust laws when it loses sales to a competitor charging non-predatory prices pursuant to a vertical, maximum-price-fixing scheme." ${ }^{41}$ In contrast, this investigation focuses on allegations on the long recognized more troublesome

Analyzing Predatory Pricing Policy, 89 Yale L.J. 213 (1979); William J. Baumol, QuasiPermanence of Price Reductions: A Policy for Prevention of Predatory Pricing, 89 Yale L.J. 1 (1979); William H. Page, The scope of Liability for Antitrust Violations, 37 Stan. L. Rev. 1445 (1985); Frank H. Easterbrook, Predatory Strategies and Counterstrategies, 48 U. Chi. L. Rev. 263 (1981); George A. Hay, Predatory Pricing, 58 Antitrust L.J. 913 (1989). To be sure, whatever the risks and tradeoffs may be when predicting what present and future benefits and harms may be invoked when considering a particular market within our national economy, including options for market entry and for competition in other areas of the national economy, especially when focused mainly on pecuniary profit, the risks and tradeoffs may be both quantitatively and qualitatively different when considering a potential cartel among large industrial firms in a much larger country than ours in which the national government plays a significant role in its own national economy in general, and in its internal firms in particular, and may have a range of short and long term interests other than the ordinary pecuniary notions of money, business, and profit, including perhaps relating to national security, that may be materially adverse to those of the United States.

${ }^{39}$ Broadcast Music, 441 U.S. at 9.

${ }^{40}$ Louis Kaplow, On the Relevance of Market Power,130 Harv. L. Rev. 1303, 1375 n.159 (2017).

41495 U.S. at 331 (emphases added)."

(Page 11 of 20) 
category of conduct that includes horizontal agreements for predatorily low prices, as well as many other forms of collusion on both price and output.

To be sure, the complaint about this more troublesome category of alleged conduct does beg an important question about why, exactly, Complainants in this investigation took the position they were not able to show antitrust injury flowing from that conduct. ${ }^{42}$ Although federal courts often do apply a predatory pricing analysis, including the requirements that plaintiffs plead and prove below-cost pricing and recoupment, to cases involving pricing as the sole or clearly predominant mechanism of exclusionary conduct, predatory pricing is not required to support a finding of antitrust injury in federal court. ${ }^{43}$ For example, in Retrophin, the district court found that "there is no alleged procompetitive aspect to the challenged conduct," and antitrust injury was sufficiently alleged where "[plaintiff's] injury-exclusion from the Relevant Markets-is inseparable from the alleged harm to competition." ${ }^{44}$ Similarly, in this investigation, the relatively small number of firms in the relatively concentrated domestic steel market, supports the inference that if there turns out to be material antitrust harm to the industry in this investigation, then that injury would also flow to Complainant, itself. ${ }^{45}$ Indeed, courts have found the antitrust injury requirement to be met where the alleged antitrust violation and the particular plaintiff's position in the impacted market, by their very nature, are such that the violation's widespread harm to the market extends to the particular plaintiff as well. ${ }^{46}$ Courts do so while also appropriately

\footnotetext{
${ }^{42}$ For some possible explanations, see supra notes 17, 38.

${ }^{43}$ See ZF Meritor, LLC v. Eaton Corp., 696 F.3d 254, 272-277, 289 (3d Cir. 2012) (concluding there was sufficient evidence of antitrust injury without requiring a showing of predatory pricing where plaintiffs did not rely solely on the exclusionary effect of defendant's prices, and instead highlighted a number of anticompetitive provisions in the alleged anticompetitive agreements).

${ }^{44}$ Retrophin, Inc. v. Questcor Pharm., Inc., 41 F. Supp. 3d 906, 913-914 (C.D. Cal. 2014) (footnote omitted) (citing Gulf States Reorganization Grp., Inc. v. Nucor Corp., 466 F.3d 961, 967-68 (11th Cir.2006) (potential competitor plaintiff demonstrated antitrust injury where it was foreclosed from entering market due to defendant monopolists' purchase of 'substantially all of the assets necessary for a potential entrant into the market to begin operations and compete;' exclusion from market was 'inseparable from the alleged harm to competition.'); 2A PHILLIP E. AREEDA \& HERBERT HOVENKAMP, ANTITRUST LAW \ 391e, at 328 (3d ed. 2007) ('If an incumbent monopolist takes steps to maintain its monopoly by foreclosing a would-be rival from entering.... [b]oth consumers and foreclosed rivals suffer antitrust injury.')).

${ }^{45}$ See Oral Argument Transcript, pp. 84-85 (discussing concentration of domestic steel industry and its relevance to the question of whether antitrust harm to the industry would be harm to the Complainant, itself).

${ }^{46}$ See Wilkv. American Medical Ass'n, 895 F.2d 352, 365, 378 (7th Cir. 1990) (affirming the district court's finding that antitrust injury was satisfied in an antitrust action under $\S 1$ of the Sherman Act for illegal boycott in restraint of trade, filed by chiropractors against the American Medical Association and seeking injunctive relief under $\S 16$ of the Clayton Act, where the evidence showed
} 
recognizing that a plaintiff's mere participation in a market is not sufficient to meet the antitrust injury requirement. ${ }^{47}$ But regardless of why Complainants in this particular investigation took the position they could not show antitrust injury, the basic question explored in this paper is whether the basic reasons set forth by the courts using the legal doctrine of antitrust injury are apposite to the setting of a Section 337 investigation.

Another example of that reasoning can be seen in Energy Conversion Devices, where there was no allegation of any agreement among the defendant firms to recoup losses from below-cost pricing, or otherwise coordinate pricing details or output details. ${ }^{48}$ As with $A R C O$, that stands in contrast to this investigation, where the complaint explicitly alleges the type of horizontal agreement generally recognized to be of significant risk of economic harm like a hard core cartel involving agreement over much more than price predation (low pricing), such as essentially full spectrum price coordination for every aspect of

\footnotetext{
“"pervasive, nationwide, effective conspiracy which by its very nature would have affected the demand curve for chiropractic services and therefore adversely affected income of chiropractors"')(citation omitted); In re Warfarin Sodium Antitrust Litig., 214 F.3d 395, 397, 40102 (3d Cir. 2000) (In a case involving alleged unlawful attempts to monopolize in violation of $\S 2$ of the Sherman Act, and reversing lower court's decision that class plaintiffs lack standing for injunctive relief under $\S 16$ of the Clayton Act, the Circuit Court found the indirect purchasers "suffer[ed] antitrust injury" because "[they] were the target of [defendant's] antitrust violation" and "[t]he excess amount paid by [the purchasers] not only is 'inextricably intertwined' with the injury [defendant] aimed to inflict, the overcharge was the aim of [defendant's] preclusive conduct").

${ }^{47}$ See, e.g., Fair Isaac Corp. v. Experian Information Solutions, Inc., 650 F.3d 1139, 1145 (8th Cir. 2011) (rejecting plaintiff's damages and injunctive relief claims and plaintiff's argument that "it has suffered an antitrust injury because ... [it] 'is the target of an illegal conspiracy or an effort to monopolize a market'..." due in part to finding that "losses stemming from [competitor's] mere existence in the market and from [plaintiff] lowering its prices to compete [] do not constitute antitrust injury"); Ginsburg v. InBev NV/SA, 623 F.3d 1229, 1235-36 (8th Cir. 2010) (rejecting indirect purchaser plaintiffs' request for divestiture under $\S 16$ of the Clayton Act, for alleged violation of $\S 7$ of that Act (unlawful merger), and holding that while "injury of higher retail beer prices . . is a type of antitrust injury," "any antitrust injury Plaintiffs could prove would be both speculative and localized" because " "brewers develop beer pricing and promotion strategies on a "local" market basis, based on an assessment of local competitive conditions"") (citation omitted)). ${ }^{48}$ Energy Conversion Devices Liquidation Trust v. Trina Solar Ltd., 833 F.3d 680, 682 (6th Cir. 2016). ("Missing from the complaint is any allegation that the competitors not only agreed to lower prices but also planned to earn back what they lost - to recoup the losses by charging anticompetitive prices in a cornered market."). The court's entire analysis in Energy Conversion Devices is focused on the long-recognized debate in the antitrust case law and academic literature about the benefits to consumers from low prices and the error costs that arise when courts too easily accept predatory pricing arguments.
}

(Page 13 of 20) 
pricing (both substance and timing of pricing from low to high and any steps in between) as well as output coordination. ${ }^{49}$

It makes good sense for a tribunal like the one in Energy Conversion Devices to have skepticism about acting against low pricing. Because consumers benefit from low prices, the tribunal has reasonable confidence about overall social benefit; and because consumers only may be harmed later if the prices are later raised to above-competitive levels and kept there, the tribunal has reasonable skepticism about risk of overall social harm. Yet, such skepticism about low pricing behavior is of little relevance to behaviors relating to the many other aspects of pricing, or to the many other aspects of output that are alleged in this investigation.

Sustained full spectrum pricing coordination can drive out competition without benefitting consumers, such as by interfering with competitors' actual or prospective business relationships with the full production team, which includes investors, suppliers, workers, collaborators, wholesalers, distributors, and the like. Similarly, successful coordination to restrict output is recognized as a classic risk to consumer harm. The harm to the market that could flow from the type of broad spectrum market manipulation alleged here is analogous to what could happen if a single massively dominant player in the market were able to effectively set the bid and ask prices and quantities for almost every attempted point of sale along the value chain for finished steel. The degree of international uproar about allegations of bid rigging around the London Interbank Offered Rate (LIBOR) over the past decade suggests broad consensus that such bid rigging would be widely seen as a serious harm to the market itself.

Put differently, not only does the complaint in this investigation allege more than was the focus of the Court's opinion in $A R C O$ by pleading both price predation - instead of no predation - plus coordination to restrain output, the complaint in this investigation goes further than what was at least the focus of the court's opinion in Energy Conversion Devices by pleading almost full spectrum price coordination - not merely predation - as well as coordination to restrain output. Indeed, the one example of Commission members expressing concern about the private antitrust injury doctrine ${ }^{50}$ involved single firm conduct alleged to be monopoly maintenance

${ }^{49}$ Complaint Under Section 337 of the Tariff Act of 1930, as Amended, at p. 2, para. 3, and pp. $17-$ 20 (Apr. 26, 2016).

50 See Certain Electrically Resistive Monocomponent Toner and "Black Powder" Preparations Therefor, Inv. No. 337-TA-253, Additional Views of Vice Chairman Anne E. Brunsdale and Commissioner Ronald A. Cass, 0088 WL 1572171, *15 (March 1988) ("A second concern is the possible absence of the sort of antitrust injury necessary to support an action under the antitrust laws.

(Page 14 of 20) 
under Sherman Act Section 2 after "lawfully acquired monopoly power" and mere disparagement of the competitor's product. ${ }^{51}$ But, again, in this investigation, the alleged conduct underlying Complainant's antitrust claim is a horizontal agreement allegedly involving conduct directed to both output restriction as well as price, which is of a type generally recognized to raise significant risk of economic harm like a hard core cartel..$^{52}$

The allegations in this investigation are different than in those cases cited by Respondents. When federal courts are faced with settings where heightened scrutiny of a plaintiff's allegations is not warranted - because there is decreased risk of over-inclusiveness in antitrust enforcement and decreased risk of chilling pro-competitive conduct - the courts caution against imposing unduly simplistic and mechanical rules regarding predatory pricing in order to avoid placing "a significant portion of anticompetitive conduct outside the reach of the antitrust laws without adequate justification." ${ }^{53}$ Importing the antitrust injury doctrine into the ITC's 337 docket may pose similar risks.

\section{Fitness to Different Categories of Statutory Protections}

Courts applying the antitrust injury doctrine have shown a keen sensitivity for the need to lower the burden imposed by the doctrine to fit the nature of the particular provisions of the underlying statute sought to be enforced. For example, courts have applied a materially lower threshold for the antitrust injury doctrine in those cases brought by private plaintiffs under Section 16 of the Clayton Act than

\footnotetext{
In private antitrust litigation, it is not sufficient for the plaintiff to make out a violation of the antitrust laws and a derivative harm to the plaintiff. The plaintiff also must show that the harm to him results directly from the injury to competition and not from some other consequence of the challenged action.").

${ }^{51}$ See id., Views of the Comm'n, at *5-6 (emphasis added).

${ }^{52}$ See, e.g. Federal Trade Comm. \& U.S. Dept. of Justice, Antitrust Guidelines for Collaborations Among Competitors, $\S 3.3$ at 10-11 (2000) (absent overriding benefits, agencies will challenge types of horizontal agreements recognized to be suspect "where the likelihood of anticompetitive harm is evident from the nature of the agreement") (emphasis added)).

53 See, e.g., ZF Meritor, 696 F.3d at 278 ("Although the Supreme Court has created a safe harbor for above-cost discounting, it has not established a per se rule of non-liability under the antitrust laws for all contractual practices that involve above-cost pricing. . . . Nothing in the case law suggests, nor would it be sound policy to hold, that above-cost prices render an otherwise unlawful exclusive dealing agreement lawful. We decline to impose such an unduly simplistic and mechanical rule because to do so would place a significant portion of anticompetitive conduct outside the reach of the antitrust laws without adequate justification.")
}

(Page 15 of 20) 
under Section 4 of that act. ${ }^{54}$ There are two differences between these two statutory provisions that explain this lower threshold: one is that Section 16 provides only injunctive relief, while Section 4 provides monetary relief; and the second is that Section 16 focuses on threat of harm rather than actual harm, which is the focus of Section $4 .{ }^{55}$ This shows that the antitrust injury doctrine itself shows sensitivity to both the underlying statute's type of harm and type of remedy.

Such sensitivity within the antitrust injury doctrine, on its own terms, shows how the doctrine may require essentially no burden in the appropriate setting. As the Supreme Court stated in Zenith Radio, "[Section] 16 ... authorizes injunctive relief upon the demonstration of 'threatened' injury [and that] remedy is characteristically available even though the plaintiff has not yet suffered actual injury." 56 Yet, because even Section 16 of the Clayton Act speaks about harm or

${ }^{54}$ See, e.g., Schoenkopf v. Brown \& Williamson Tobacco Corp., 637 F.2d 205, 210 (3d Cir. 1980) ("courts ... acknowledge a lower threshold standing requirement for section 16 than for section 4").

${ }^{55}$ See Matina Kesaris, Antitrust Standing of Target Corporations to Enjoin Hostile Takeovers under Section 16 of the Clayton Act, 55 Fordham L. Rev. 1039, 1045-46 (1987) ("Lower courts often have noted that the standing requirements under section 16 are less stringent than those under section 4 . While section 4 requires a showing of injury in fact, section 16 requires only a threat of injury.") (footnotes omitted, citing, inter alia, Cargill, Inc. v. Monfort of Colorado, Inc., 479 U.S. 104, 111 (1986); Zenith Radio Corp. v. Hazeltine Research Inc., 395 U.S. 100, 130 (1969)); Cia Petrolera Caribe, Inc. v. Arco Caribbean, Inc., 754 F.2d 404, 407-08 (1st Cir. 1985) ("In Hawaii v. Standard Oil Co., 405 U.S. 251, 260, 92 S.Ct. 885, 890, 31 L.Ed.2d 184 (1972), the Supreme Court noted an important difference between the requirements of $\S 16$ and those of $\S 4$. The Court pointed out that a $\S 4$ claim requires an injury to 'business or property' that $\S 16$ omits. The Court noted that, by contrast, $\S 16$ provides that 'any individual threatened with injury by an antitrust violation may ... sue for injunctive relief against violations of the antitrust laws...' Hawaii v. Standard Oil Co., 405 U.S. [251,] 261, 92 S.Ct. at 890-91 (emphasis added). Plainly, Congress empowered a broader range of plaintiffs to bring $\S 16$ actions because the standards to be met are less exacting than those under $\S 4$; under $\S 16$, a plaintiff need show only a threat of injury rather than an accrued injury. The Court's remarks in Hawaii reaffirm its conclusions in Zenith Radio Corp. v. Hazeltine Research, Inc., 395 U.S. 100, 89 S.Ct. 1562, 23 L.Ed.2d 129 (1969). .."); Lucas Auto. Eng'g, Inc. v. Bridgestone/Firestone, Inc., 140 F.3d 1228, 1234 (9th Cir. 1998) ("To maintain an antitrust divestiture suit, a private plaintiff must generally meet all the requirements that apply to the damages plaintiff, except that the injury itself need only be threatened, damage need not be quantified, and occasionally a party too remote for damages might be granted an injunction.") (citation omitted).

56395 U.S. at 130. As the Third Circuit in In re Warfarin Sodium Antitrust Litig. explained,

Recovery under section 16 is best understood in how it differs from recovery under section 4 of the Clayton Act. While relief sought pursuant to section 4 of the Clayton Act requires proof of loss and any damages proven are trebled, injunctive relief under section 16 only requires a threat of loss. . . An antitrust plaintiff proceeding under section 16 must, however, still demonstrate that the injury in question is "injury of the type the antitrust laws were intended to prevent. . . ." A section 4 plaintiff's standing is tested by an application of a number of factors designed to determine if the asserted damage goes 
its threat to a particular plaintiff that is "by a violation of the antitrust laws," antitrust injury doctrine in the setting of a Clayton Act Section 16 injunction case still requires a type of proximate causation between the particular harm or threatened harm to the plaintiff and the underlying harm or threatened harm to the market that the antitrust laws are designed to prevent. ${ }^{58}$

The same reasoning leads to the opposite conclusion where the statutory regime avoids such a proximate causation and instead focuses on the direct harm to the market. Unlike the focus in Section 16 of the Clayton Act on harm to the plaintiff, the provisions in the ITC's statute - Section 337 - explicitly require the ITC to deal directly with harms to the industry or the market (rather than to the particular plaintiff), as explored earlier. ${ }^{59}$ Where the statute protects the market rather than the individual complainant, the antitrust injury doctrine's own internal logic does not compel the imposition of a burden to show harm to the particular private actor bringing the complaint.

\section{Self-Initiation}

Such intense focus on Section 337's direct protections for the industry and the market does raise an interesting question about the role of the particular complainant in an antitrust case brought under that statutory provision. There appears to be broad consensus that the ITC can self-initiate an antitrust case under Section 337 and in such a proceeding would not be required to apply the antitrust injury doctrine to itself or to anyone else. For example, while the ITC's independent Office of Unfair Import Investigations (OUII) took the position in this investigation that in its view the ITC should import the private antitrust injury doctrine when a private party brings an antitrust complaint before the ITC, even OUII recognized that if the ITC self-initiated the present investigation, then the

beyond speculation and, that if there is cognizable damage, the plaintiff is the appropriate person to assert it for antitrust purposes. . . Section 16 is not as demanding, but it does require a showing that there is "a significant threat of injury from $[a]$. . violation of the antitrust laws...."

214 F.3d 395, 399 (3d Cir. 2000) (citations omitted) (emphasis added).

57 15 U.S.C. $\$ 26$ (Section 16 of the Clayton Act).

58 See also Daniel Berger \& Roger Bernstein, An Analytical Framework for Antitrust Standing, 86

Yale. L.J. 809, 810-13 (1977) (reviewing basic contours of the antitrust standing problem).

${ }^{59}$ See supra Part II.A.

(Page 17 of 20) 
private antitrust injury doctrine would not apply. ${ }^{60}$ OUII is correct that the ITC, like the Federal Trade Commission (FTC), has independent authority to institute and litigate antitrust investigations under section $337 .{ }^{61}$

Yet, it seems odd to make the legal distinction OUII is making in an investigation such as this one (between a self-initiated and a party-initiated proceeding) given that the ITC voted to initiate this investigation after the complaint was filed. After all, if it turned out there really were harm to a domestic industry or trade and commerce in this case, it would be strange for the ITC to have to dismiss this action and deprive itself of the benefit of the advance work and ongoing work of the private party, only to either sit idle or expend the resources to - flying solo that time - reinitiate and proceed to completion.

\section{E. ITC as an Additional Option to More Traditional Venues}

Keeping the private antitrust injury doctrine out of ITC practice also leaves society with a relatively low cost additional option to have private litigants bring antitrust causes of action in a forum - the ITC - that offers a distinct blend of characteristics not available in the federal courts or before the other agencies. ${ }^{62}$ When a private litigant brings an action in district court under the Clayton Act, the defendant is exposed to at least four significant categories of risk: (1) damages; (2) treble damages, costs, and attorney fees; (3) injunctions to make structural modifications to their business; and (4) class actions. At the ITC, the defendant essentially can only be kept out of the U.S. economy. There is always the risk of over-deterrence and in-terrorem threats to extract settlements; and both the courts

\footnotetext{
${ }^{60}$ The Reply Submission of the Office of Unfair Import Investigations Regarding the Commission's December 19, 2016 Questions, at p. 8 (Feb. 1, 2017); Response of the Office of Unfair Import Investigations to Public Submissions Regarding Issues under Review, at p. 4 n. 2 (Apr. 3, 2017).

${ }^{61}$ See 19 U.S.C. $\S 1337$ (b)(1) (stating that the Commission has authority to "investigate any alleged violation of this section on complaint under oath or upon its initiative") (emphasis added); see also Certain Apparatus for Flow Injection Analysis and Components Thereof, Inv. No. 337-TA-151, 1984 WL 63180, *1 (Nov. 1, 1984) ("This investigation was instituted by the Commission on its own motion ...."). Agencies like the ITC operating under Article II of the Constitution are not constrained by the same standing doctrine that constrains the courts operating under Article III. As the Supreme Court explained in O'Shea, "[Clayton Act s]ection 16's requirement of 'threatened injury,' 15 U.S.C. $§ 26$, dovetails with Article III's requirement that in order to obtain forwardlooking relief, a plaintiff must face a threat of injury that is both "'real and immediate," not "conjectural" or "hypothetical." O'Shea v. Littleton, 414 U.S. 488, 494 (1974) (quoting Golden, 394 U.S. at 109-10)." See also, In re New Motor Vehicles Canadian Export Antitrust Litigation, 522 F.3d 6, 14 (1st Cir 2008).

${ }^{62}$ To be sure, each option offers a distinct set of relative costs and benefits and one size rarely fits all.
}

(Page 18 of 20) 
and the ITC have various rules at their disposal to police bad-faith litigation tactics. After district court litigation, the reviewing courts typically have a black-box jury verdict and the opinion of a single jurist. After litigation before the ITC, the reviewing courts typically have an extensive administrative record, with the opportunity for it to have been bolstered by the legal advocacy on behalf of the public interest from the ITC's independent Office of Unfair Import Investigations ("OUII") as well as potentially by the ITC's extensive staff of economists, industry experts, and investigators, and that typically includes an administrative law judge's opinion and the opinion of a plurality of Commissioners. District court proceedings in complex commercial cases like antitrust typically span 3-5 years. ITC 337 proceedings typically span 18 months. Further, while government antitrust enforcement by the Department of Justice Antitrust Division (DoJ) and the FTC inherently involve the political impact of the Executive Branch both as the direct supervisor of the Department and as the one designating the FTC Chair from the members who are typically in the President's party (and typically backed up by a majority in the President's party), the ITC is statutorily mandated to have (when all seats are filled) a politically balanced even number of Commissioners with a Chair required to rotate person and party every two years. ${ }^{63}$ This all adds up to a view of the ITC as one option for private litigants to bring antitrust actions that provides a unique blend of characteristics not available through the other venues. ${ }^{64}$ And in recognition that ITC action might clash with the foreign policy or domestic policy goals of the Administration, ${ }^{65}$ it should be kept in mind that ITC Section 337 remedial orders are subject to a statutory period of Presidential Review. ${ }^{66}$

\footnotetext{
${ }^{63}$ Furthermore, while the DoJ and FTC have wide prosecutorial discretion when deciding whether to bring or proceed with an action, the Commission's discretion regarding whether to institute investigations based on well-pleaded complaints is limited. See 19 U.S.C. § 1337(b)(1) ("The Commission shall investigate any alleged violation of this section on complaint under oath or upon its initiative.") (emphasis added); see also Amgen Inc. v. U.S. Intern. Trade Comm'n, 902 F.2d 1532, 1536-37 (Fed. Cir. 1990); Certain Bar Clamps, Bar Lamp Pads, and Related Packaging, Display, and other Materials, Inv. No. 337-TA-429, Comm'n Op., 2001 WL 36114993, at *2 (Feb. 13, 2001).

${ }^{64}$ To be sure, the ITC makes errors like any other agency and is subject to a range of pressures relating to politics and fashion. And ITC Commissioners and staff as individual professionals are no better or worse than their wonderful counterparts staffing and leading the many sister commissions and agencies across the government. But, the major structural differences intentionally built into the ITC that distinguish it from those other commissions and agencies do have important impacts on how the ITC operates differently than those other commissions and agencies. For a discussion of many of those differences, see Kieff, supra note 9.

65 See, e.g., EEOC v. Arabian Am. Oil Co., 499 U.S. 244, 248 (1991) (presumption against extraterritoriality "serves to protect against unintended clashes between our laws and those of other nations which could result in international discord").

${ }^{66}$ Indeed, President Carter disapproved the Commission's issuance of remedial orders on policy grounds in a prior antitrust matter. See Steel Pipe, 43 FR 17789 (1978).
} 


\section{CONCLUSION}

In sum, the private antitrust injury doctrine is neither explicitly called for by the ITC's statute, nor by the substantive antitrust statute. It also does not seem to fit either the architecture of Section 337 or the practice of 337 investigations at the ITC that raise antitrust arguments like those in the present investigation. Therefore, the antitrust injury doctrine should not be imported into the ITC's Section 337 portion of its docket. 